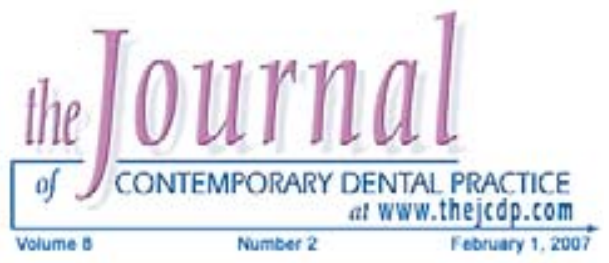

\title{
Effect of Two Light-emitting Diode (LED) and One Halogen Curing Light on the Microleakage of Class V Flowable Composite Restorations
}

\author{
Nuray Attar, DDS, PhD; Yonca Korkmaz, DDS, PhD
}

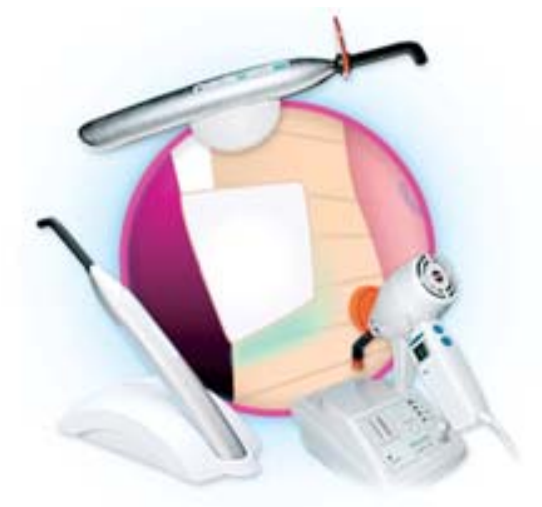

Abstract

Aim: The disadvantages of light cured composite resin materials with respect to microleakage are predominantly a result of polymerization shrinkage upon curing. It has been shown curing methods play a significant role in polymerization shrinkage of light-cured composite resins. The purpose of this study was to investigate the effect of light-emitting diode (LED) light curing units (LCUs) compared with a halogen LCU on microleakage of three different flowable composites using self-etch adhesives.

Methods and Materials: A total of 63 extracted human premolars were prepared with standardized Class V cavity preparations on the buccal and lingual surfaces of each tooth. The occusal margin of the cavities was located on the enamel and the gingival margin was on dentin. Teeth were randomly assigned to three groups of 21 teeth each as follows: Group 1: Adper Prompt L-Pop + Filtek Flow (3M ESPE); Group 2: AdheSE + Tetric Flow (Ivoclar, Vivadent); and Group 3: Clearfil Protect Bond + Clearfil Protect Liner F (Kuraray Medical Inc.). All the groups were subdivided into three groups according to the curing lights used $(n=7)$. Two LED LCUs, Elipar FreeLight and Elipar FreeLight 2 (3M ESPE), and one halogen-based LCU, Hilux Expert (Benlioglu ), were used. All teeth were then immersed in $0.5 \%$ basic fuchsin dye solution for 24 hours after thermocycling (500 cycles; between $5^{\circ} \mathrm{C}$ to $\left.55^{\circ} \mathrm{C}\right)$. The teeth then were longitudinally sectioned and observed under a stereomicroscope (40X magnification) by two examiners. The degree of dye penetration was recorded separately for enamel and dentin. Data were analyzed with the Kruskal-Wallis and Mann-Whitney tests with the Bonferroni correction.

Results: No statistically significant differences in microleakage were observed between groups either on enamel or dentin $(p>0.05)$.

(C) Seer Publishing 
Conclusion: With the limitation of this in vitro study, the differences in microleakage between LCUs used were not statistically significantly different. Elipar Free Light 2 reduces curing time which can be considered as an advantage.

Keywords: Light-emitting diode, LED, microleakage, flowable composite, self-etch adhesive

Citation: Attar N, Korkmaz Y. Effect of Two Light-emitting Diode (LED) and One Halogen Curing Light on the Microleakage of Class V Flowable Composite Restorations. J Contemp Dent Pract 2007 February;(8)2:080-088.

\section{Introduction}

Halogen light curing units (LCUs) have been used for many years, however, they have some drawbacks. For instance, their bulbs have a limited life span (40-100 hours); as the performance of the bulb progressively diminishes, a decrease in favorable properties of composite materials occurs. ${ }^{1,2}$ In addition the vitality of the pulp can be affected by rising temperatures during polymerization. ${ }^{3}$ LCUs also require approximately 40 seconds of exposure time for adequate polymerization of the composite resin. ${ }^{4}$

Innovative light-emitting diode (LED) technology has been improved for light curing dental materials in order to overcome the inadequacies of the halogen LCU's. ${ }^{5}$ LED LCU's are inexpensive, low voltage devices which have a long life expectancy. They are very compact and can be designed to emit specific light waves. The units have better resistance to shock and vibration, and they are also portable and safe.,6 Although they have lower light emission, LEDs have the ability to cure like other light sources or slightly less. ${ }^{7}$ In addition, the temperature increase is significantly less and does not pose a threat to pulpal tissue. ${ }^{8,9}$ Saving time during the light curing process is one of the most important aspects to clinicians who use the incremental filling technique. ${ }^{10}$

Self-etching primers designed to simplify and shorten bonding procedures were developed recently. ${ }^{11}$ They enable composite to enamel bonding without treatment of a separate phosphoric acid gel for etching of the enamel surface. $^{11-15}$

Early flowable composite formulations were characterized by Bayne and others. ${ }^{16}$ They are purported to offer higher flow, better adaptation to the internal cavity wall, easier insertion,
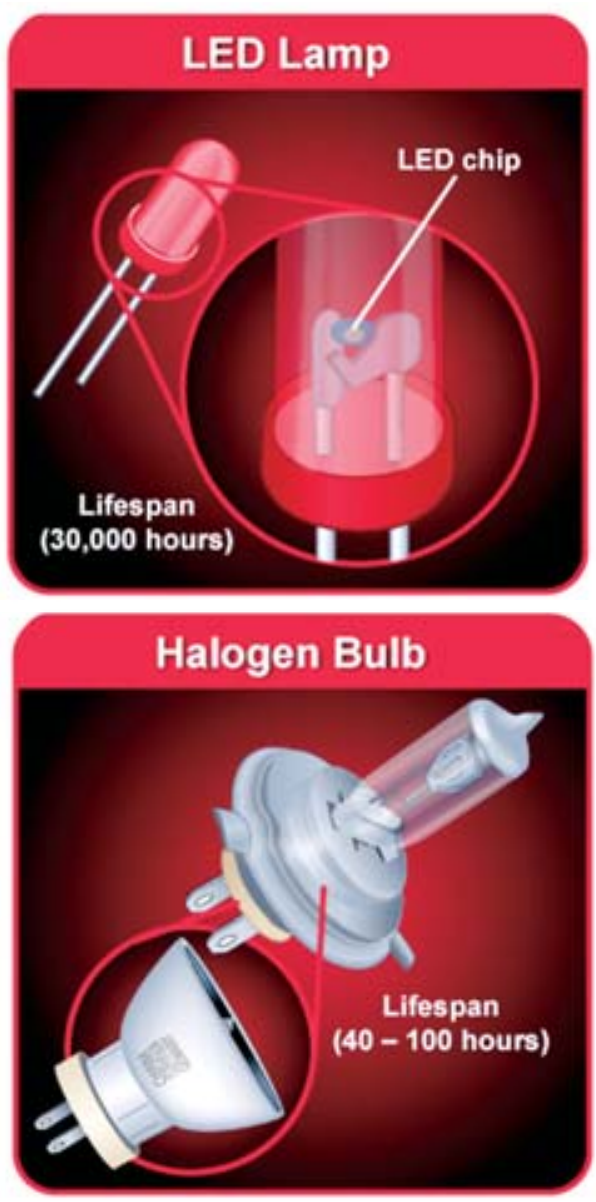

and greater elasticity than previously available products. ${ }^{17}$ One of the indications of the flowable composites is the restoration of Class V defects. ${ }^{18}$ Composites present an inherent disadvantage consisting of polymerization shrinkage during setting. ${ }^{19-21}$ This shrinkage depends on the:

- configuration of the restoration (C factor),

- type and shade of the composite resin,

- viscoelastic properties of the dentin bonding system used in the adhesive procedure,

- the restorative technique and the light curing protocol. ${ }^{10,22-29}$ 
Polymerization shrinkage can result in gap formation between the cavity walls and composite resin..$^{30,31}$ Gap formation contributes to microleakage, permitting the passage of bacteria and oral fluids from the oral cavity. ${ }^{32}$ Post operative sensitivity, pulpal inflammation, and secondary caries may occur because of microleakage. ${ }^{33}$

Several studies have reported ways to reduce microleakage in Class V lesions. ${ }^{32,34,35}$ Although curing lights and bonding materials are improving rapidly, there is no currently available technique that can prevent gap formation especially at either the cementum or dentin-restoration junctions. ${ }^{32,35,36}$

The aim of this study was to evaluate the effects of LED LCU's compared to a halogen LCU on the microleakage of three different flowable composites with self-etch adhesives.

\section{Methods and Materials}

A total of 63 freshly extracted, caries free, human premolars without cracks or previous restorations were selected for the study. Calculi and residual soft tissue were carefully removed, and the teeth were stored at room temperature $\left(23^{\circ} \mathrm{C}-27^{\circ} \mathrm{C}\right)$ in distilled water within one month after extraction.

Standard Class $\mathrm{V}$ cavity preparations (mesiodistal width of $3 \mathrm{~mm}$, occluso-gingival length of $2 \mathrm{~mm}$, and a depth of $1.5 \mathrm{~mm}$ ) were prepared on buccal and lingual surfaces with a high-

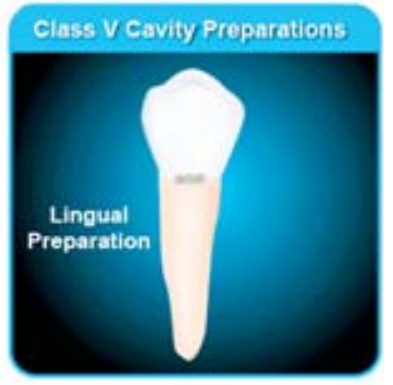

speed hand-piece with air-water spray and a \#1090 diamond fissure bur (Diatech Dental AG, Heerbrugg Switzerland). New burs were used after every four preparations. Each preparation was designed with the occlusal margin in enamel and the cervical margin in dentin.

The teeth were divided into three groups according to the flowable composite used to restore the teeth (Table1) (Figure1).

Each group was subdivided into three subgroups for three LCU's ( $n=7$ ) (Table 2) (Figure 2).

Table 3 shows the experimental groups in the study.

Group I: Adper Prompt L-Pop self-etch adhesive was applied with an active bluster and rubbed for 15 seconds then gently blown with air and light cured as follows:

- (Group la): Ten seconds with an Elipar Free Light followed by an application of Filtek Flow

Table 1. Materials and their self-etch adhesives used in this study.

\begin{tabular}{|c|c|c|c|c|}
\hline Group & & duct & Batch & Manufacturer \\
\hline 1 & $\begin{array}{l}\text { Adhesive } \\
\text { System } \\
\text { Flowable } \\
\text { Composite }\end{array}$ & $\begin{array}{l}\text { Adper Prompt } \\
\text { L-Pop } \\
\text { Filtek Flow }\end{array}$ & \begin{tabular}{|l|}
201130 \\
3700A3
\end{tabular} & $\begin{array}{l}\text { 3M ESPE Dental Products, } \\
\text { St. Paul, MN, USA }\end{array}$ \\
\hline 2 & $\begin{array}{l}\text { Adhesive } \\
\text { System } \\
\text { Flowable } \\
\text { Composite }\end{array}$ & $\begin{array}{l}\text { AdheSE } \\
\text { Tetric Flow }\end{array}$ & \begin{tabular}{|l|} 
F22511 \\
G05181
\end{tabular} & $\begin{array}{l}\text { Ivoclar Vivadent AG, } \\
\text { Schaan, Liechtenstein }\end{array}$ \\
\hline 3 & $\begin{array}{l}\text { Adhesive } \\
\text { System } \\
\text { Flowable } \\
\text { Composite }\end{array}$ & $\begin{array}{l}\text { Protect Bond } \\
\text { Protect Liner F }\end{array}$ & $\begin{array}{l}61118 \\
0049\end{array}$ & $\begin{array}{l}\text { Kuraray Medical Inc., } \\
\text { Sakazu,Kurashiki, Japan }\end{array}$ \\
\hline
\end{tabular}




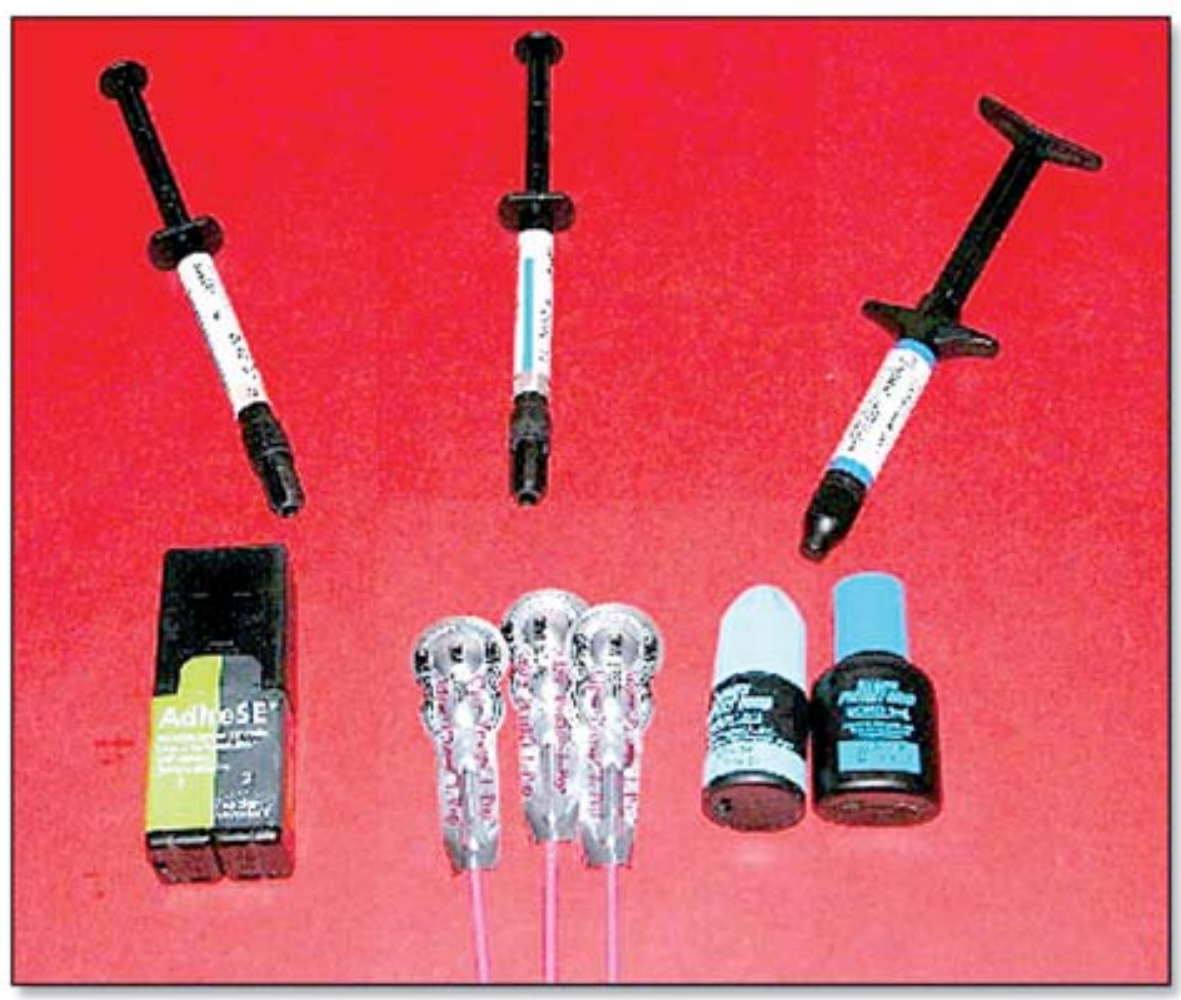

Figure 1. Flowable composites and their self-etch adhesives used in this study.

Table 2. Light curing units (LCUs) used in this study.

\begin{tabular}{|c||c||c|c|}
\hline LCU & Type & Manufacturer & $\begin{array}{c}\text { Intensity } \\
\text { (approx.) }\end{array}$ \\
\hline \hline $\begin{array}{c}\text { Elipar Free } \\
\text { Light }\end{array}$ & LED & $\begin{array}{c}\text { 3M ESPE Dental Products, } \\
\text { St. Paul, MN, USA }\end{array}$ & $400 \mathrm{~mW} / \mathrm{cm} 2$ \\
\hline \hline $\begin{array}{c}\text { Elipar Free } \\
\text { Light 2 }\end{array}$ & LED & $\begin{array}{c}\text { 3M ESPE Dental Products, } \\
\text { St. Paul, MN, USA }\end{array}$ & $1000 \mathrm{~mW} / \mathrm{cm} 2$ \\
\hline \hline Hilux Expert & Halogen & $\begin{array}{r}\text { Benlioglu Dental, Bülbülderesi Cad.8'A, } \\
\text { Ankara, Turkey }\end{array}$ & $500 \mathrm{~mW} / \mathrm{cm} 2$ \\
\hline
\end{tabular}
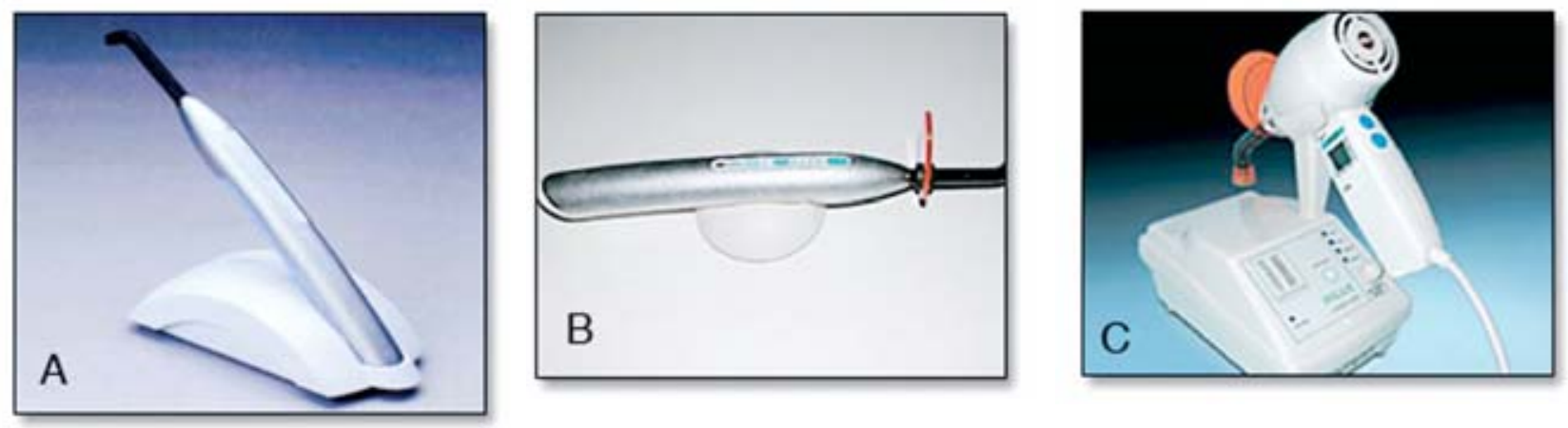

Figure 2. Light curing units used in this study. A. Elipar Free Light B. Elipar Free Light 2 C. Hilux Expert 
Table 3. Experimental Groups.

\begin{tabular}{|c|c|c|}
\hline \multicolumn{2}{|c|}{ Groups } & Applleation Procedures \\
\hline \multirow{3}{*}{ Group I } & Group la & Adper Prompt L-Pop + Filtek Flow + Elipar Free Light \\
\hline & Group lb & Adper Prompt L-Pop + Filtek Flow + Elipar Free Light 2 \\
\hline & Group Ic & Adper Prompt L-Pop + Filtek Flow + Hilux Expert \\
\hline \multirow{3}{*}{ Group II } & Group lla & AdheSE + Tetric Flow + Elipar Free Light \\
\hline & Group IIb & AdheSE + Tetric Flow + Elipar Free Light 2 \\
\hline & Group Ilc & AdheSE + Tetric Flow + Hilux Expert \\
\hline \multirow{3}{*}{ Group III } & Group IIla & Protect Bond + Protect Liner F + Elipar Free Light \\
\hline & Group IIIb & Protect Bond + Protect Liner F + Elipar Free Light 2 \\
\hline & Group IIlic & Protect Bond + Protect Liner F + Hilux Expert \\
\hline
\end{tabular}

and cured for another 40 seconds with the same light

- (Group lb): Five seconds with an Elipar Free Light 2 followed by an application of Filtek Flow and cured for another 20 seconds with the same light

- (Group Ic): Ten seconds with an Hilux Expert followed by an application of Filtek Flow and cured for another 40 seconds with the same light

Group II: The primer component of AdheSE self-etch adhesive was applied for 30 seconds and gently air dried followed by the bonding agent and light cured as follows:

- (Group Ila): Ten seconds using the Elipar Free Light

- (Group Ilc): Ten seconds using the Hilux Expert

- (Group Ilb): Five seconds using the Elipar Free Light 2

Tetric Flow was then applied and cured as follows:

- (Group Ila): 40 seconds using the Elipar Free Light

- (Group IIc): 40 seconds using the Hilux Expert

- (Group Ilb): 20 seconds using the Elipar Free Light 2.

Group III: Protect Bond, the primer, was applied for 20 seconds, gently air dried, then the bonding resin was applied gently air dried and light cured as follows:
- (Group IIla): Ten seconds using the Elipar Free Light

- (Group Illb): Five seconds using the Elipar Free Light 2

- (Group IIlc): Ten seconds using the Hilux Expert

Protect Liner F was then applied and cured as follows:

- (Group IIla): 40 seconds using the Elipar Free Light

- (Group IIlb): 20 seconds for Elipar Free Light 2

- (Group IIIc): 40 seconds using the Hilux Expert

The restorative materials were placed using a single increment since the depths were less than $2 \mathrm{~mm}$. The LCU's were placed to the buccal or lingual surfaces at close range $(0-1 \mathrm{~mm})$. All preparation of teeth, restorations, and finishing were performed by one operator. After storage in water at $37^{\circ} \mathrm{C}$ for 24 hours, the restorations were finished with fine-grit finishing diamond burs (Diatech Dental AG, Heerbrugg Switzerland) and polished with a graded series of Sof-Lex XT Polishing Discs (3M ESPE, St. Paul, MN, USA).

The specimens were then thermocycled 500 times each at $5^{\circ} \mathrm{C}$ and $55^{\circ} \mathrm{C}$. The specimens were subsequently sealed with a composite resin (TPH Spectrum, Dentsply de Tray, Constanz, Germany) at the root apices, and two coats of fingernail varnish were applied on the tooth 1.5 $\mathrm{mm}$ short of the margins to be exposed to dye. The restorations were then immersed in $0.5 \%$ 
aqueous basic fuchsin dye for 24 hours. They subsequently were rinsed under running water to remove dye and dried at room temperature. The specimens were sectioned longitudinally through the center of the restorations with a diamond saw (Isomed Buehler, Ltd, Lake Bluff, IL, USA). Dye penetration was quantified for the enamel and dentin margins separately. The degree of dye penetration was then graded at $40 \mathrm{X}$ original magnification with a stereomicroscope (Leica MS5 Singapore, Singapore) using the following scale (a 0-3 scoring system was used to describe the severity of infiltration): ${ }^{37}$

$$
\begin{aligned}
& 0=\text { No dye penetration } \\
& 1=\text { Dye penetration up to one-third } \\
& \text { of the cavity wall }
\end{aligned}
$$

2 = Dye penetration more than onethird, but less than two-thirds of the cavity wall

3 = Dye penetration more than twothirds, or to the full extent of the cavity wall

The linear microleakage scores for the groups were analyzed using Kruskal-Wallis and MannWhitney $U$ tests with the Bonferroni correction for pair wise comparisons at a significance level of $p<0.05$.

Table 4 shows the distribution of dye penetration scores at the enamel and dentin margins in all groups.

Tetric Flow, Protect Liner F, and Filtek Flow exhibited no statistically significant differences in values between the LCU's on enamel and dentin interfaces $(p>0.05)$. In the Hilux Expert and Elipar Free Light 2 LCU groups there were no statistically significant differences between flowable composites on either enamel or dentin interfaces $(p>0.05)$.

More microleakage was found at the dentin interface when the Filtek Flow was cured with the Elipar Free Light. However, when the Bonferroni correction for pair wise comparison was used, no statistically significant differences between flowable composites were found in the Elipar Free Light groups ( $p>0.05)$.
Comparing the microleakage scores between enamel and dentin margins with each restorative material using different LCU's, there was a slight increase in leakage at the dentin margins but this was not statistically significant $(p>0.05)$.

\section{Discussion}

Light cured composite resin materials have several advantages such as control of the contour during placement of the restoration, better color stability, and a more complete polymerization compared to chemically activated materials. ${ }^{38}$ An inherent disadvantage of these materials is they contract during light polymerization. ${ }^{39}$ Microleakage is a phenomenon of the diffusion of organic or inorganic substances into a tooth through the interface between the restorative material and the tooth structure. ${ }^{40}$ Microleakage may result from many factors, such as the extent of the marginal gap, polymerization shrinkage of materials used, the degradation of the particular bonding or restorative material used, dissolution of linear or smear layers, and varying coefficients of thermal expansion for restorations. ${ }^{41-43}$

A variety of curing lights are available for the photo polymerization of light cured dental resins. The most common approach is the conventional halogen LCU. It has been shown that halogen curing light deliver an inadequate light intensity. ${ }^{44}$ LED technology may overcome some of the drawbacks of halogen LCU's; consequently, LED technology has a promising future. ${ }^{44}$ It has been reported significantly less microleakage occurred at the dentin/cementum interface when restorations were cured with an LED unit compared to curing with the standard halogen LCU, however, no significant difference in microleakage was found between LCU's at the enamel interface. ${ }^{45}$

In this study there were no significant differences between LED and halogen LCU's both in enamel and dentin. In an other study, there was also no significant difference in microleakage reported between LED LCUs compared with halogen LCU at enamel margins, however, at dentin margins only the Elipar Freelight (soft start) was found to significantly reduce microleakage. ${ }^{45}$ In order to prevent microleakage it is clear all margins must be kept in enamel. However, root caries, abfraction, and abrasion lesions have their margins in dentin or cementum. ${ }^{32}$ Hence, the 
Table 4. Microleakage and mean leakage scores.

\begin{tabular}{|c|c|c|c|c|c|c|}
\hline \multicolumn{2}{|c|}{ Groups } & \multicolumn{5}{|c|}{ Leakago Scores } \\
\hline & & 0 & 1 & 2 & 3 & Moan \\
\hline \multirow{2}{*}{ Group la } & Enamel & 10 & 4 & 0 & 0 & 0.2857 \\
\hline & Dentin & 0 & 8 & 6 & 0 & 1.4286 \\
\hline \multirow{2}{*}{ Group Ib } & Enamel & 14 & 0 & 0 & 0 & 0.00 \\
\hline & Dentin & 6 & 4 & 2 & 2 & 1.00 \\
\hline \multirow{2}{*}{ Group Ic } & Enamel & 12 & 2 & 0 & 0 & 0.1429 \\
\hline & Dentin & 6 & 4 & 0 & 4 & 1.1429 \\
\hline \multirow{2}{*}{ Group lla } & Enamel & 14 & 0 & 0 & 0 & 0.00 \\
\hline & Dentin & 2 & 12 & 0 & 0 & 0.8571 \\
\hline \multirow{2}{*}{ Group IIb } & Enamel & 14 & 0 & 0 & 0 & 0.00 \\
\hline & Dentin & 10 & 2 & 2 & 0 & 0.4286 \\
\hline \multirow{2}{*}{ Group IIc } & Enamel & 10 & 2 & 2 & 0 & 0.4286 \\
\hline & Dentin & 8 & 6 & 0 & 0 & 0.4286 \\
\hline \multirow{2}{*}{ Group Illa } & Enamel & 10 & 4 & 0 & 0 & 0.2857 \\
\hline & Dentin & 2 & 12 & 0 & 0 & 0.8571 \\
\hline \multirow{2}{*}{ Group IIIb } & Enamel & 10 & 4 & 0 & 0 & 0.2857 \\
\hline & Dentin & 6 & 8 & 0 & 0 & 0.5714 \\
\hline \multirow{2}{*}{ Group IIIc } & Enamel & 12 & 2 & 0 & 0 & 0.1429 \\
\hline & Dentin & 12 & 2 & 0 & 0 & 0.1429 \\
\hline
\end{tabular}

occlusal margins of the cavities were placed on the enamel and the gingival margins on dentin in this study.

Self-etch adhesives have recently become available and combine the functions of primer and adhesive components which has eliminated the need for separate acid etch and rinsing steps. ${ }^{46}$ One disadvantage is self-etch adhesives are not able to etch the enamel as deeply as phosphoric acid. ${ }^{47}$ Many dentists prefer to etch the enamel to obtain retention for self-etch adhesives even without clinical evidence of efficacy. ${ }^{48}$ In this study, the enamel was not etched with phosphoric acid. Despite significant improvements in dentin bonding systems, no system is currently able to completely prevent the formation of contraction gaps, especially at the cementum/dentin restoration junction. ${ }^{35,36}$
A new class of "flowable composites" has been marketed since 1996. Their flow characteristics differ from hybrid composites allowing them to be easily inserted and adapted to cavity surfaces using an injection technique. ${ }^{16,49}$ Estafan and Estafan have reported flowable composites demonstrate resistance to microleakage in both enamel and cementum/dentin margins similar to TPH hybrid composite..$^{50}$

Restorative materials, when tested in vitro, fail to simulate the dynamic intra thermal changes induced by routine eating and drinking. Thermocycling is often employed in laboratory experiments to simulate stresses in the oral cavity. The absence of an outward flow of dentinal fluid and a completely altered dentinal surface due to extraction lead to a poor correlation between in vivo and in vitro 
conditions. ${ }^{51}$ Fuchsin dye penetration was chosen for this study because it provided a simple, relatively cheap, quantitative, and comparable method of evaluating the various composite systems. ${ }^{52}$

\section{Conclusion}

It may be concluded that microleakage still a reality with the adhesive systems, flowable composites, and LCU's used in this study. Two LED LCU's did not eliminate microleakage and showed similar microleakage with a halogen LCU. The Elipar Free Light 2 has a higher intensity resulting in a reduction of curing time. Saving time is an important issue for busy clinicians especially when using the incremental filling technique which requires repeated curing of each

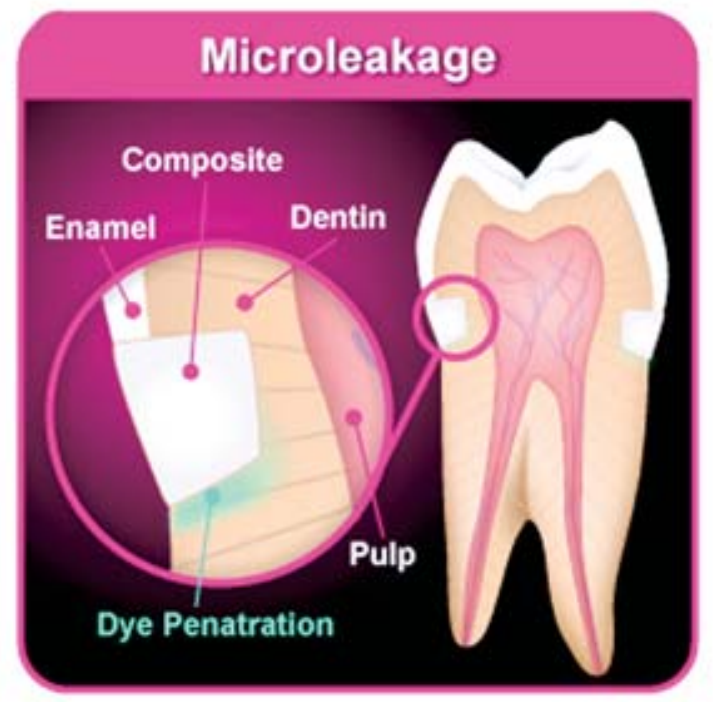
increment after insertion.

\section{References}

1. Oberholzer TG, Du Preez IC, Kidd M. Effect of LED curing on the microleakage, shear bond strength and surface hardness of a resin-based composite restoration. Biomater 2005; 26: 3981-3986.

2. Fowler CS, Swartz ML, Moore BK. Efficacy testing of visible-light-curing- units. Oper Dent 1994; 19 : 47-52.

3. Hannig M, Bott B. In-vitro pulp chamber temperature rise during composite resin polymerization with various light curing sources. Dent Mater 1999; 15: 275-281.

4. Besnault C, Pradelle-Plasse N, Picard B,Colon P. Effect of a LED versus halogen light cure polymerization on the curing characteristics of three composite resins. Am J Dent 2003; 16: 323-328.

5. Mills RW. Blue light emitting diodes--another method of light curing? Br Dent J 1995; 178: 169.

6. Mills RW, Uhl A, Jandt KD. Optical power outputs, spectra and dental composite depths of cure, obtained with blue light emitting diode (LED) and halogen light curing units (LCUs). Br Dent J 2002; 193: 459-463.

7. Dunn WJ, Bush AC. A comparison of polymerization by light-emitting diode and halogen-based lightcuring units. J Am Dent Assoc 2002 ;133: 335-341.

8. Hofmann N, Hugo B, Klaiber B. Effect of irradiation type (LED or QTH) on photo-activated composite shrinkage strain kinetics, temperature rise, and hardness. Eur J Oral Sci 2002; 110: 471-479.

9. Soh MS, Yap AU, Siow KS. The effectiveness of cure of LED and halogen curing lights at varying cavity depths. Oper Dent 2003; 28: 707-715.

10. Pradelle-Plasse N, Besnault C, Souad N, Colon P. Influence of new light curing units and bonding agents on the microleakage of Class V composite resin restorations. Am J Dent 2003; 16: 409-413.

11. Perdigao J, Lopes M. Dentin bonding-questions for the new millennium. J Adhes Dent 1999; 1: 191-209.

12. Barkmeier WW, Los SA, Triolo PT Jr. Bond strengths and SEM evaluation of Clearfil Liner Bond 2. Am J Dent 1995; 8: 289-293.

13. Hannig M, Reinhardt KJ, Bott B. Self-etching primer vs phosphoric acid: an alternative concept for composite-to-enamel bonding. Oper Dent 1999; 24: 172-180.

14. Perdigao J, Lopes L, Lambrechts P, Leitao J,Van Meerbeek B, Vanherle G. Effects of a self-etching primer on enamel shear bond strengths and SEM morphology. Am J Dent 1997; 10: 141-146.

15. Hannig M, Bock $\mathrm{H}$, Bott $B$, Hoth-Hannig W.Inter-crystallite nanoretention of self-etching adhesives at enamel imaged by transmission electron microscopy. Eur J Oral Sci 2002; 110: 464-470.

16. Bayne SC, Thompson JY, Swift EJ Jr, Stamatiades P, Wilkerson M. Characterization of firstgeneration flowable composites. J Am Dent Assoc 1998; 129: 567-577.

17. Payne JH 4th. The marginal seal of Class II restorations: flowable composite resin compared to 
injectable glass ionomer. J Clin Pediatr Dent 1999; 23: 123-130.

18. Unterbrink GL, Liebenberg WH. Flowable resin composites as "filled adhesives": literature review and clinical recommendations. Quintessence Int 1999; 30: 249-257.

19. Attar N, Turgut MD, Güngör $\mathrm{CH}$. The effect of flowable composite resins as gingival increments on the microleakage of posterior resin composites. Oper Dent 2004; 29:162-167.

20. Yap AU, Soh MS, Han TT, Siow KS. Influence of curing lights and modes on cross-link density of dental composites. Oper Dent 2004; 29: 410-415.

21. Mehl A, Hickel R, Kunzelmann KH. Physical properties and gap formation of light-cured composites with and without 'softstart-polymerization'. J Dent 1997; 25: 321-330.

22. Feilzer AJ, De Gee AJ, Davidson CL. Setting stress in composite resin in relation to configuration of the restoration. J Dent Res 1987; 66: 1636-1639.

23. Bouschlicher MR, Vargas MA, Boyer DB. Effect of composite type, light intensity, configuration factor and laser polymerization on polymerization contraction forces. Am J Dent 1997; 10: 88-96.

24. Yearn JA. Factors affecting cure of visible light activated composites. Int Dent J 1985; 35: 218-225.

25. Ferracane JL, Aday P, Matsumoto H, Marker VA. Relationship between shade and depth of cure for light-activated dental composite resins. Dent Mater 1986; 2: 80-84.

26. Kemp-Scholte CM, Davidson CL. Complete marginal seal of Class V resin composite restorations effected by increased flexibility. J Dent Res 1990; 69: 1240-1243.

27. Lutz E, Krejci I, Oldenburg TR. Elimintion of polymerization stress at the margins of posterior resin restortions A new restoration technigue. Quintessence Int 1986; 17: 777-784.

28. Uno S, Asmussen E. Effect on bonding of curing through dentin. Acta Odontol Scand 1991; 49: 317320.

29. Losche GM. Marginal adaptation of Class II composite composite fillings :quided polymeriztion vs reduced light intensity. J Adhes Dent 1999; 1: 31-39.

30. Bowen RL, Nemoto K, Rapson JE. Adhesive bonding of various materials to hard tooth tissues: forces developing in composite materials during hardening. J Am Dent Assoc 1983; 106: 475-477.

31. Davidson CL, de Gee AJ, Feilzer A. The competition between the composite-dentin bond strength and the polymerization contraction stress. J Dent Res 1984; 63: 1396-1399.

32. St Georges AJ, Wilder AD Jr, Perdigao J, Swift EJ Jr. Microleakage of Class V composites using different placement and curing techniques: an in vitro study. Am J Dent 2002; 15: 244-247.

33. Bergenholtz G, Cox CF, Loesche WJ, Syed SA. Bacterial leakage around dental restorations: its effect on the dental pulp. J Oral Pathol 1982; 11: 439-450.

34. Versluis A, Douglas $W H$, Cross $M$, Sakaguchi $R L$. Does an incremental filling technique reduce polymerization shrinkage stresses. J Dent Res 1996; 75: 871-878.

35. May KN Jr, Swift EJ Jr, Wilder AD Jr, Futrell SC. Effect of a surface sealant on microleakage of Class V restorations. Am J Dent 1996; 9: 133-136.

36. Walker RS, Burgess JO. Microleakage of class $\mathrm{V}$ composite restorations with different visible light curing methods. J Dent Res 1999; 78:155 (Abstr 397).

37. Yap AU, Yap WY, Yeo EJ, Tan JW, Ong DS. Effects of finishing/polishing techniques on microleakage of resin-modified glass ionomer cement restorations Oper Dent 2003; 28: 36-41.

38. Burgess JO, Walker RS, Porche CJ, Rappold AJ. Light curing--an update. Compend Contin Educ Dent 2002; 23: 889-892.

39. Yap AU, Wang HB, Siow KS, Gan LM. Polymerization shrinkage of visible-light-cured composites. Oper Dent 2000; 25: 98-103.

40. de Almeida JB, Platt JA, Oshida Y, Moore BK, Cochran MA, Eckert GJ. Three different methods to evaluate microleakage of packable composites in Class II restorations. Oper Dent. 2003; 28: 453-460.

41. Oilo G. Biodegradation of dental composites/glassionomer cements. Adv Dental Res 1992; 6: 50-54.

42. Fortin D, Swift EJ Jr, Denehy GE, Reinhardt JW. Bond strength and microleakage of current dentine adhesives. Dental Mater 1994; 10: 253-258.

43. Suzuki M, Jordan RE, Boksman L. Posterior composite resin restorative-clinical considerations. In: Vanherie G, Smith DC, eds. Posterior Composite Resin Dental Restorative materials. St Paul 3M 
Co: Peter Szulc Publishing Co, Netherlands 1985:455.

44. Pilo R, Oelgiesser D, Cardash HS. A survey of output intensity and potential for depth of cure among light-curing units in clinical use. J Dent 1999; 27: 235-241.

45. Oberholzer TG, Schunemann M, Kidd M. Effect of LED curing on microleakage and microhardness of Class V resin-based composite restorations. Int Dent J 2004; 54: 15-20.

46. Sensi LG, Lopes GC, Monteiro S Jr, Baratieri LN, Vieira LC. Dentin bond strength of self-etching primers/adhesives. Oper Dent 2005; 30: 63-68.

47. Perdigao J. Dentin bonding as function of dentin structure. Dent Clin North Am 2002; 46: 277-301.

48. Perdigao J, Carmo AR, Anauate-Netto C, Amore R, Lewgoy HR, Cordeiro HJ, Dutra-Correa M, Castilhos N. Clinical performance of self-etch adhesives at 18 months. Am J Dent 2005; 18: 135-140.

49. Attar N, Tam LE, McComb D. Flow, strength, stiffness and radiopacity of flowable resin composites. J Can Dent Assoc. 2003 ;69:516-521.

50. Estafan AM, Estafan D. Microleakage study of flowable composite resin systems. Compend Contin Educ Dent 2000; 21: 705-708.

51. Pashley DH. Clinical considerations of microleakage. J Endod 1990; 16: 70-77.

52. Yap AUJ, Wong ML, Lim ACY. The effect of polishing systems on microleakage of tooth colored restoratives: Part 2 Composite and polyasid- modified composite resins J Oral Rehabil 2000; 27: 205-210.

\section{About the Authors}

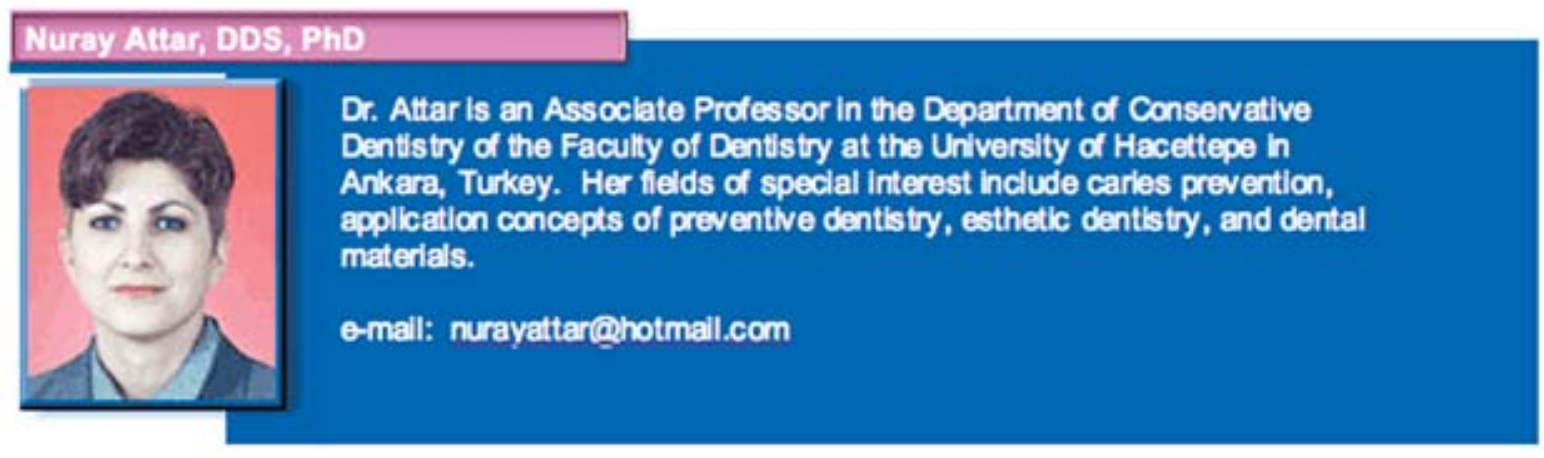

\section{Yonea Korkmaz, DDS, PhD}

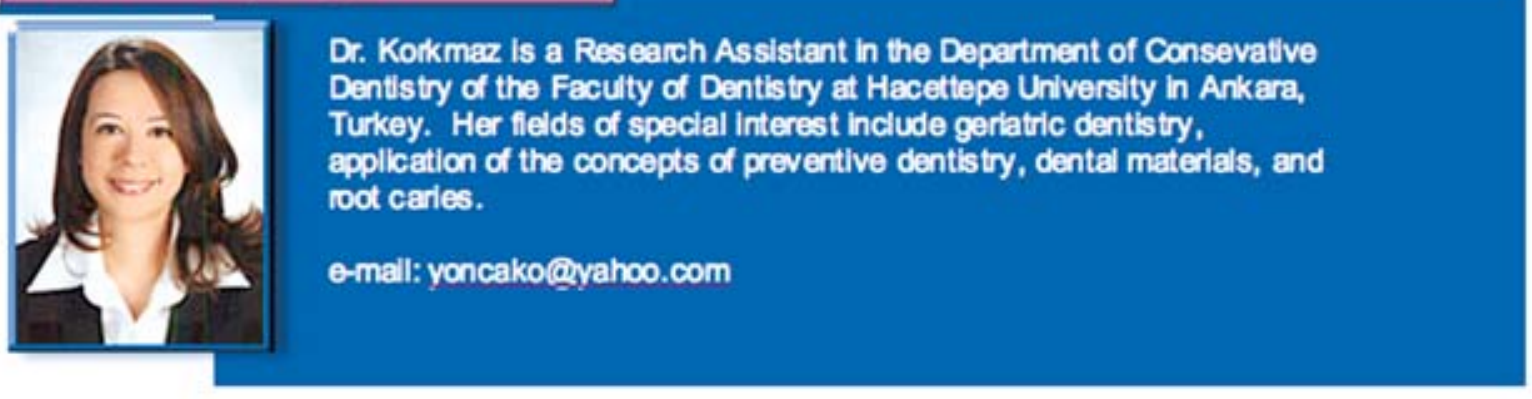

